\title{
UNIVERSITY OF LUND RADIOCARBON DATES IV
}

\author{
SÖREN HAKANSSON
}

Radiocarbon Dating Laboratory, Department of Quaternary Geology

University of Lund, Sweden

\section{INTRODUCTION}

The $\mathrm{C}^{14}$ measurements reported here were made in this laboratory between October 1969 and September 1970. The measuring technique and equipment, and the treatment of samples are the same as reported previously (R., 1968, v. 10, p. 36-37; R., 1970, v. 12, p. 534).

The remark, "undersized; diluted", in Comments means the sample did not produce enough $\mathrm{CO}_{2}$ to fill the counter to normal pressure and "dead" $\mathrm{CO}_{2}$ from anthracite was introduced to make up the pressure. "\% sample" indicates amount of $\mathrm{CO}_{2}$ derived from the sample present in the diluted counting gas; the rest is "dead" $\mathrm{CO}_{2}$. Organic carbon content reported for bone samples is calculated from yield of $\mathrm{CO}_{2}$ by combustion of pretreated collagen.

Age calculations are based on a contemporary value equal to 0.950 of the activity of the NBS oxalic-acid standard and on a half-life for $\mathrm{C}^{14}$ of $5568 \mathrm{yr}$. Results are reported in years before 1950 (years B.P.), and in the A.D./B.C. scale. Errors quoted $( \pm 1 \sigma)$ include the standard deviations of the count rates for the unknown sample, the contemporary standard, and the background. Corrections for deviations from the "normal" $\mathrm{C}^{13}$ / $\mathrm{G}^{12}$ ratio for terrestrial plants $\left(\delta \mathrm{C}^{13}=-25.0 \%\right.$ in the P.D.B. scale) are applied for all samples. $\delta \mathrm{C}^{13}$ values quoted are relative to the P.D.B. standard.

The description of each sample is based on information provided by the person submitting the sample to the laboratory.

\section{ACKNOWLEDGMENTS}

The author thanks Kerstin Lundahl for sample preparations and routine operation of the dating equipment, and $\mathrm{R}$. Ryhage and his staff at the mass-spectrometric laboratory of Karolinska Inst., Stockholm, for making the $\mathrm{C}^{13}$ analyses. Special thanks are due Christian Cavallin for assistance with the electronic equipment.

\section{SAMPLE DESCRIPTIONS}

I. GEOLOGIC SAMPLES

A. Sweden

\section{Lu-135. Torreberga, peat}

\author{
$1850 \pm 60$ \\ A.D. 100 \\ $\delta C^{13}=-27.6^{6 / 0}$
}

Sandy peat from island in ancient lake at Torreberga, $10 \mathrm{~km} \mathrm{~S}$ of Lund, S Sweden (55 $37^{\prime} \mathrm{N}$ Lat, $13^{\circ} 15^{\prime} \mathrm{E}$ Long). Coll. 1967 and subm. by G. Digerfeldt, Dept. Quaternary Geol., Univ. of Lund. Peat was formed during period of rising water level in ancient lake. Pollenanalytical dating Zone SA 1 (Nilsson, 1935, 1961a). Pretreated with HCl and $\mathrm{NaOH}$. Comment (G.D.): date confirms pollen-analytical dating. For 
additional dates from Torreberga, see Torreberga series (R., 1970, v. 12, p. 536-537).

\section{Lu-135A. Torreberga, humic acid}

$1860 \pm 55$

A.D. 90

$\delta C^{13}=-29.2 \%$

Acid-precipitated part of $\mathrm{NaOH}$-soluble fraction from material used for Lu-135.

\section{Lu-326. Juleboda}

$8220 \pm 85$

6270 B.C.

Sample from lump of peat, ca. $1 / 2 \mathrm{~m}^{3}$ in size, found on shore $50 \mathrm{~m}$ $\mathrm{N}$ of mouth of small river Julebodaån, Ravlunda parish, $\mathrm{E}$ coast of Scania ( $55^{\circ} 45^{\prime} 30^{\prime \prime} \mathrm{N}$ Lat, 14 $12^{\circ}$ 00" E Long). Coll. 1969 by Y. Cederholm and subm. by T. Nilsson, Dept. Quaternary Geol., Univ. of Lund. Comment (T.N.): peat contained small bones (phalanges and os penis) of gray seal (Halichoerus grypus) and many macroscopic plant remains, e.g., twigs, pine cones and seeds, hazelnuts, seeds of Menyanthes trifoliata, and fruit of Cornus sanguinea. It may be characterized as a limnic peat rich in drifted material. Dated by pollen analysis to middle of Scanian pollen zone BO 2. Very good agreement between pollen-analytical date and $\mathrm{C}^{14}$ date (cf. Nilsson, 1964). Peat must be derived from submarine peat earlier known to exist as a narrow stretch in very shallow water along Baltic coast near site (Nilsson, 1961b, p. 101-104).

\section{Stordalen series}

Peat samples from mire $2 \mathrm{~km} \mathrm{NW}$ of Stordalen R.R. Sta., Torneträsk area, Torne Lappmark, N Sweden $\left(68^{\circ} 20^{\prime} \mathrm{N}\right.$ Lat, $19^{\circ} 00^{\prime} \mathrm{E}$ Long). Coll. 1963 and subm. by M. Sonesson, Dept. of Plant Ecol., Univ. of Lund. Dating is part of study on vegetational dynamics and peat development in Torneträsk area (Sonesson, 1968, 1969). Depths refer to surface of mire. Lu-333 pretreated with $\mathrm{HCl}$ only (small sample); all other samples pretreated with $\mathrm{HCl}$ and $\mathrm{NaOH}$.

\section{Lu-331. Stordalen, Sample 1, peat}

$5240 \pm 90$

3290 в.C.

$\delta C^{13}=-28.0 \%$

Highly humified peat, depth $60 \mathrm{~cm}$, just above mineral substratum. Comment: undersized; diluted; $68 \%$ sample.

\section{Lu-331A. Stordalen, Sample 1, humic acid}

Acid-precipitated part of $\mathrm{NaOH}$-soluble fraction from material used for Lu-331.

\section{Lu-332. Stordalen, Sample 2, peat}

Highly humified peat, depth $22.5 \mathrm{~cm}$, directly below the obviously secondary surface peat. 
Lu-332A. Stordalen, Sample 2, humic acid

$$
\begin{gathered}
\mathbf{1 8 9 0} \pm \mathbf{7 5} \\
\text { A.D. } 60 \\
\delta C^{13}=-25.6 \%
\end{gathered}
$$

Acid-precipitated part of $\mathrm{NaOH}$-soluble fraction from material used for Lu-332.

\section{Lu-435. Stordalen, Sample 4, peat}

$$
\begin{aligned}
& \mathbf{1 1 1 0} \pm \mathbf{5 0} \\
& \text { A.D. 840 } \\
& \delta C^{13}=-25.8 \% 0
\end{aligned}
$$

Slightly humified peat, depth $20 \mathrm{~cm}$, from lowest part of secondary surface peat (almost exclusively Dicranum elongatum).

\section{Lu-435A. Stordalen, Sample 4, humic acid}

$$
\begin{array}{r}
\mathbf{1 2 0 0} \pm \mathbf{5 0} \\
\text { A.D. } \mathbf{7 5 0} \\
\delta C^{13}=-25.5 \%
\end{array}
$$

Acid-precipitated part of $\mathrm{NaOH}$-soluble fraction from material used for $\mathrm{Lu}-435$.

\section{Lu-333. Stordalen, Sample 3, Bp 133}

$4700 \pm 70$

2750 B.C.

$\delta C^{13}=-27.7 \%$

Highly humified sandy peat, depth 37 to $45 \mathrm{~cm}$, in transition zone from underlying mineral substratum to peat in pals-formation (pals = permafrost mound). Comment: sample undersized; diluted; $83 \%$ sample. General Comment: contamination from penetrating roots was suspected and humic acid fraction from the 3 samples that yielded enough such material was dated for comparison. For Sample 1 and 2, age difference between peat and humic acid fraction is normal, indicating little or no contamination from penetrating roots. For Sample 4, humic acid fraction is slightly older than peat fraction, indicating that such contamination may have caused slight rejuvenation of peat.

\section{Vassijaure series}

Peat from mire at Vassijaure, ca. $0.8 \mathrm{~km} \mathrm{NE}$ of pt. 514.22, Torne Lappmark, N Sweden (68 $25^{\prime} \mathrm{N}$ Lat, $18^{\circ} 20^{\prime} \mathrm{E}$ Long). Coll. 1963 and subm. by M. Sonesson. Dating is part of study on vegetational dynamics and peat development in Torneträsk area (Sonesson, 1968, 1969, 1970). Depths given refer to surface of mire. For other dates in same series see R., 1969, v. 11, p. 443-445. All samples pretreated with $\mathrm{HCl}$ and $\mathrm{NaOH}$.

\section{Lu-334. Vassijaure, $65 \mathrm{~cm}$, peat}

$$
\begin{aligned}
\mathbf{3 4 2 0} \pm \mathbf{6 0} \\
\mathbf{1 4 7 0} \text { в.c. } \\
\delta G^{13}=-26.7 \%
\end{aligned}
$$

Slightly humified peat, depth $65 \mathrm{~cm}$, in transition zone from underlying Paludella-Calliergon stramineum peat to Sphagnum lindbergii peat. Distinct increase of Betula in pollen diagram at this level. 
Lu-334A. Vassijaure, $65 \mathrm{~cm}$, humic acid

Acid-precipitated part of $\mathrm{NaOH}$-soluble fraction from material used for Lu-334.

Lu-433. Vassijaure, $37.5 \mathrm{~cm}$, peat

$1860 \pm 55$

A.D. 90

$\delta C^{13}=-26.1 \%$

Slightly humified peat, depth $37.5 \mathrm{~cm}$, in transition zone from underlying Sphagnum fuscum peat to Sphagnum lindbergii peat.

Lu-433A. Vassijaure, $37.5 \mathrm{~cm}$, humic acid

$1850 \pm 55$

A.D. 100

$\delta C^{13}=-26.6 \%$

Acid-precipitated part of $\mathrm{NaOH}$-soluble fraction from material used for $\mathrm{Lu}-433$.

\section{Lu-434. Vassijaure, $27.5 \mathrm{~cm}$, peat}

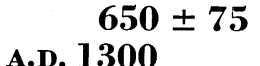

$\delta C^{13}=-26.4 \%$

Slightly humified peat, depth $27.5 \mathrm{~cm}$, in transition zone from underlying Sphagnum lindbergii peat to Sphagnum fuscum peat.

\section{Lu-434A. Vassijaure, $27.5 \mathrm{~cm}$, humic acid}

$\quad \mathbf{7 6 0} \pm \mathbf{6 0}$
A.D. 1190
$\delta C^{13}=-26.6 \%$
$m$ material used for Lu-434.

\section{Lu-335. Luopakte, Bp 140, 115 to $125 \mathrm{~cm}$}

$7480 \pm 115$

5530 B.C.

$\delta C^{13}=-27.1 \%$

Highly humified peat from perennially frozen mire at Luopakte, on Mt. Luovare, $1.2 \mathrm{~km}$ SSE of pt. 627.89, Torne Lappmark, N Sweden (68 $8^{\circ} 13^{\prime} \mathrm{N}$ Lat, $19^{\circ} 25^{\prime} \mathrm{E}$ Long). Sample from 115 to $125 \mathrm{~cm}$ below surface just above mineral substratum. Coll. 1963 and subm. by M. Sonesson. Comment: sample undersized; diluted; $53 \%$ sample. Date based on 3 1-day counts. Pretreated with $\mathrm{HCl}$ only.

\section{Siretorp series}

Ciontinuation of samples dated from profile on distal side of complex Littorina beach ridge with brackish lagoon sediments at Siretorp, Sölvesborg, Blekinge (56 $01^{\prime} \mathrm{N}$ Lat, 14 ${ }^{\circ} 37^{\prime} \mathrm{E}$ Long). Coll. 1968 and subm. by B. E. Berglund, Dept. Quaternary Geol., Univ. of Lund. Other dates from this site were reported previously (R., 1970, v. 12, p. 539-541). Pretreated with $\mathrm{HCl}$ and $\mathrm{NaOH}$.

\section{Lu-366. Siretorp 14 \\ Brackish gyttja, 90 to $92 \mathrm{~cm}$.}

$5430 \pm 65$

3480 B.c.

$\delta C^{13}=-21.8 \%$ 


\section{Lu-367. Siretorp 15}

Brackish gyttja, 86 to $89 \mathrm{~cm}$.

\section{Bysjön series}

Sediment from Lake Bysjön near coast of Central Blekinge, SE Sweden $\left(56^{\circ} 11^{\prime} \mathrm{N}\right.$ Lat, $15^{\circ} 08^{\prime} \mathrm{E}$ Long). Alt $8 \mathrm{~m}$; size $200 \times 300 \mathrm{~m}$; max. depth $2.3 \mathrm{~m}$; mean depth $1.7 \mathrm{~m}$. Lacustrine sediments investigated to date some horizons in pollen diagrams and to obtain a value of sedimentation rate. Samples were cut out from cores taken with Livingstone sampler (diam. $60 \mathrm{~mm}$ ). Water depth $150 \mathrm{~cm}$ at sampling point. Depths given in sample titles are below lake water level. Pollen zones according to Berglund (1966b). Coll. 1969 by C. E. Nylander; subm. by B. E. Berglund. All samples except Lu-466 and Lu-467 more or less undersized; diluted. Amount of $\mathrm{CO}_{2}$ from sample is given in Comments below as "\% sample".

\section{Lu-374. Bysjön 1, 415 to $420 \mathrm{~cm}$}

$$
\begin{gathered}
\mathbf{4 4 3 0} \pm \mathbf{8 0} \\
\mathbf{2 4 8 0} \text { B.c. } \\
\delta C^{13}=-33.7 \% \text { \% }
\end{gathered}
$$

Lacustrine detritus gyttja as in following samples. Pollen spectra indicates middle of SB 1. Comment: $75 \%$ sample.

\section{Lu-375. Bysjön 2, 410 to $415 \mathrm{~cm}$}

$4460 \pm 70$

Dated to check Lu-374. Comment: $85 \%$ sample.

2510 B.C.

$$
\delta C^{13}=-30.7 \%
$$

Lu-376. Bysjön 3, 375 to $380 \mathrm{~cm}$

Just at the Zone Boundary SB 1/SB 2. Comment: $87 \%$ sample.

\section{Lu-377. Bysjön 4,340 to $345 \mathrm{~cm}$}

In the middle of SB 2, dating Sub-Boreal rise of Betula curve and increased human influence. Comment: $93 \%$ sample.

Lu-378. Bysjön 5, 315 to $320 \mathrm{~cm}$ sample.

In upper part of SB 2, dating a Juniperus peak. Comment: $82 \%$

\section{Lu-379. Bysjön 6, 305 to $310 \mathrm{~cm}$}

$$
2220 \pm 55
$$

Just at the Zone Boundary SB/SA, dating decrease of Juniperus. Comment: $72 \%$ sample; date based on 3 1-day counts. 
Lu-380. Bysjön 7, 290 to $295 \mathrm{~cm}$

$1890 \pm 55$

A.D. 60

$\delta C^{13}=-31.2 \%$

In lower part of SA 1, dating minimum of human influence. Comment: $67 \%$ sample; date based on 3 1-day counts.

Lu-381. Bysjön 8, 255 to $260 \mathrm{~cm}$

$$
\begin{array}{r}
1620 \pm 60 \\
\text { A.D. 330 } \\
\delta C^{13}=-30.6 \% 0
\end{array}
$$

In SA 1, dating end of short phase with increased human influence. Comment: $81 \%$ sample.

\section{Lu-382. Bysjön 9, 245 to $250 \mathrm{~cm}$}

$$
\begin{gathered}
1480 \pm 65 \\
\text { A.D. } 470 \\
\delta C^{18}=-30.9 \% \circ
\end{gathered}
$$

In upper part of SA 1, dating rise of Fagus curve in period with slight human influence. Comment: $64 \%$ sample.

\section{Lu-466. Bysjön 13, 230 to $235 \mathrm{~cm}$}

$$
\begin{array}{r}
\mathbf{1 2 4 0} \pm \mathbf{5 0} \\
\text { A.D. 710 } \\
\delta C^{13}=-27.6 \%
\end{array}
$$

At the Zone Boundary SA 1/SA 2; 1st Fagus peak lying between this and following sample.

\section{Lu-467. Bysjön 14, 215 to $220 \mathrm{~cm}$}

$$
\begin{array}{r}
1150 \pm 50 \\
\text { A.D. 800 } \\
\delta C^{13}=-30.0 \%
\end{array}
$$

In lower part of SA 2, dating slight rise of Juniperus curve and increasing human influence.

\section{Lu-383. Bysjön 10, 195 to $200 \mathrm{~cm}$}

$$
\begin{gathered}
1020 \pm 70 \\
\text { A.D. 930 } \\
\delta C^{13}=-31.2 \%
\end{gathered}
$$

Dating starting point of period with strong human influence. Comment: $56 \%$ sample.

\section{Lu-468. Bysjön 15, 184 to $191 \mathrm{~cm}$

$$
\delta C^{13}=-31.3 \%
$$

Dating rise of the Secale curve. Comment: $93 \%$ sample.

\section{Lu-384. Bysjön 11, 175 to $180 \mathrm{~cm}$}

$$
\begin{aligned}
& \mathbf{7 2 0} \pm \mathbf{8 0} \\
& \text { A.D. } 1230 \\
& \delta C^{1 s}=-30.6 \%
\end{aligned}
$$

With following sample, dates a very high Juniperus peak and a maximum of human influence. Comment: $40 \%$ sample.

\section{Lu-415. Bysjön 12, 165 to $170 \mathrm{~cm}$}

$$
\begin{array}{r}
660 \pm 80 \\
\text { A.D. } 1290 \\
\delta C^{13}=-30.3 \%
\end{array}
$$

Comment: $42 \%$ sample.

General Comment (B.E.B.): sedimentation rate seems unusually constant and quite high between 2600 and 700 B.P., i.e., ca. $90 \mathrm{~mm} / 100 \mathrm{yr}$. This makes it possible to express pollen values in absolute numbers. 


\section{Mt. Kullen biostratigraphy series}

Mt. Kullen is a ridge with summit at $187 \mathrm{~m}$ above m.s.l., on peninsula in NW Scania, S Sweden $\left(56^{\circ} 17^{\prime} \mathrm{N}\right.$ Lat, $12^{\circ} 31^{\prime} \mathrm{E}$ Long). Ice left area early, and biostratigraphy of some basins is expected to give valuable information on chronology and vegetational and soil development during Late-glacial time. Studies are concentrated to 2 fens, Björkeröds Mosse on S slope with calcareous sediments in lower part, and Håkulls Mosse on ridge with non-calcareous sediments. Pollen zones according to Nilsson (1961a) and Berglund (1966a). Preliminary results reported by Berglund (1971).

\section{Björkeröds Mosse}

A shallow, longish fen basin $($ ca. $400 \times 40 \mathrm{~m})$, alt $75 \mathrm{~m}$ in clayey till. Samples from core taken in central part with Digerfeldt sampler (cross section $100 \times 100 \mathrm{~mm}$ ). Sampling point is named BP 3b. Samples 0 to 4 are calcareous, 5 to 9 non-calcareous. Coll. 1969 and subm. by B. E. Berglund. Depths refer to surface of fen. All samples pretreated with $\mathrm{HCl}$ for complete removal of carbonates. Carbonate fraction coll. from 2 samples and dated separately for comparison with organic fraction.

\section{Lu-368. Björkeröd 0, 364 to $369 \mathrm{~cm}$}

Muddy calcareous clay, in upper part of DR 1.

\section{Lu-337. Björkeröd 1, 328 to $333 \mathrm{~cm}$}

Clayey calcareous gyttja, in lower part of Bö.

$$
13,380 \pm 120
$$

\section{Lu-338. Björkeröd 2, 320 to $325 \mathrm{~cm}$, organic}

Clayey calcareous gyttja, in middle of Bö.

$12,700 \pm 110$

10,750 в.c. $\delta C^{13}=-22.5 \%$

\section{Lu-338c. Björkeröd 2, carbonate}

$$
\begin{aligned}
& 13,160 \pm 135 \\
& 11,210 \text { в.C. } \\
& \delta C^{13}=+0.2 \%
\end{aligned}
$$

Carbonate fraction extracted from material used for Lu-338. Comment: corrections for deviations from "normal" $\mathrm{C}^{13} / \mathrm{C}^{12}$ ratio for terrestrial plants $\left(\delta C^{13}=-25.0 \%\right.$ in P.D.B. scale $)$ are applied also for carbonate samples.

\section{Lu-339. Björkeröd 3, 310 to $315 \mathrm{~cm}$}

$12,770 \pm 110$

Clayey calcareous gyttja, in upper part of Bö.

10,820 в.C.

Lu-340. Björkeröd 4, 305 to $310 \mathrm{~cm}$, organic

Calcareous clay gyttja, in DR 2. 
Lu-340c. Björkeröd 4, carbonate

$13,500 \pm 95$

11,550 в.C.

$\delta C^{13}=-1.3 \%$

Carbonate fraction extracted from material used for Lu-340. Comment: same as for $\mathrm{Lu}-338 \mathrm{c}$.

\section{Lu-406. Björkeröd 5, 253 to $255 \mathrm{~cm}$}

$11,110 \pm 115$

Clayey fine detritus gyttja, at Zone Boundary AL/DR 3.

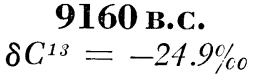

9160 B.C.

\section{Lu-407. Björkeröd 6, 245 to $247 \mathrm{~cm}$}

$11,010 \pm 100$

9060 B.C.

Clayey fine detritus gyttja, in lowest part of DR 3 .

Lu-408. Björkeröd 7, 225 to $227 \mathrm{~cm}$

$$
\begin{gathered}
10,320 \pm 105 \\
\mathbf{8 3 7 0} \text { B.C. } \\
\delta C^{13}=-21.8 \%
\end{gathered}
$$

Clayey fine detritus gyttja, in uppermost part of DR 3 .

Lu-409. Björkeröd 8, 223 to $225 \mathrm{~cm}$

$10,160 \pm 105$

8210 B.C.

Clayey fine detritus gyttja, in transition zone DR 3-PB.

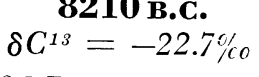

\section{Lu-410. Björkeröd 9, 194 to $196 \mathrm{~cm}$}

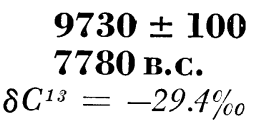

Coarse detritus gyttja, in upper part of PB.

General Comment (B.E.B.): dates for samples 0 to 4 have much higher values than expected. The cause must be the carbonate content of the water, which gave submerged plants a mixture of pre-Quaternary inactive carbon and atmospheric carbon with normal radiocarbon content. Consequently, the carbonate fractions have slightly higher values than corresponding organic fractions. Dates for samples 1 to 4 are almost identical, though real age differences exist. Samples 5 to 9 give quite reliable: results.

\section{Ryssjön series}

Sediment from lake Ryssjön at coast of Central Blekinge, SE Sweden $\left(56^{\circ} 10^{\prime} \mathrm{N}\right.$ Lat, $15^{\circ} 05^{\prime} \mathrm{E}$ Long). Alt $3 \mathrm{~m}$; size $300 \times 400 \mathrm{~m}$; max. depth $2.3 \mathrm{~m}$; mean depth $1.7 \mathrm{~m}$. Lake was transgressed by Littorina Sea. Samples taken to date earliest part of transgression. Upper lacustrine part of sediments was studied for vegetational development by C. E. Nylander (R., 1969, v. 11, p. 436-437). Samples from cores taken with Livingstone sampler (diam. $60 \mathrm{~mm}$ ). Depths given are below water level. Water depth $230 \mathrm{~cm}$ at sampling point. Coll. 1969 and subm. by R. Liljegren and B. E. Berglund. All samples somewhat undersized; diluted. Pretreated with $\mathrm{HCl}$ only. 
Lu-314. Ryssjön 12

$6710 \pm 90$

4760 в.c.

$\delta C^{13}=-26.7 \%$

Slightly brackish gyttja, 515 to $519 \mathrm{~cm}$. Comment: $61 \%$ sample; date based on 3 1-day counts.

Lu-315. Ryssjön 13

$6910 \pm 90$

4960 B.c.

$\delta C^{13}=-30.1 \%$

Limnic gyttja, 521 to $525 \mathrm{~cm}$. Comment: $78 \%$ sample.

\section{Lu-316. Ryssjön 14}

$7200 \pm 105$

5250 B.c.

$\delta C^{13}=-25.6 \%$

Slightly brackish gyttja, 530 to $534 \mathrm{~cm}$. Comment: $55 \%$ sample; date based on 3 1-day counts.

\section{Lu-317. Ryssjön 15}

$7350 \pm 100$

5400 B.C.

Limnic gyttja, 535 to $539 \mathrm{~cm}$. Comment: $75 \%$ sample.

\section{Färsksjön series}

Samples from profile with brackish lagoon sediments from Lake Färsksjön at Eriksberg, Åryd parish, Blekinge $\left(56^{\circ} 11^{\prime} \mathrm{N}\right.$ Lat, $15^{\circ} 00^{\prime}$ E Long), to study shore displacement in middle parts of Blekinge and compare it with results from E Blekinge (Berglund, 1964). Site was transgressed by Littorina Sea and is presently a partly overgrown lake. Cores taken with Livingstone sampler ( $60 \mathrm{~mm}$ diam.) consist of a series of brackish gyttjas over- and underlain by limnic gyttjas. Pollen diagram covers main part of Atlantic and Early Sub-Boreal zones. Transgressions named according to Berglund (1964). Depths are below water level. Water depth $150 \mathrm{~cm}$. Coll. 1968 and subm. by R. Liljegren and B. E. Berglund. All samples somewhat undersized; diluted. Pretreated with $\mathrm{HCl}$ only.

\section{Lu-318. Färsksjön 1}

$4840 \pm 70$ 2890 B.C.

Slightly brackish gyttja, 580 to $584 \mathrm{~cm}$. Beginning of 2nd Sub-Boreal transgression. Comment: $88 \%$ sample.

\section{Lu-319. Färsksjön 2}

$4970 \pm 75$ 3020 B.c.

Limnic gyttja, 586 to $590 \mathrm{~cm}$. Between 1st and 2nd Sub-Boreal transgression. Comment: $83 \%$ sample.

Lu-320. Färsksjön 3

Brackish gyttja, 597 to $601 \mathrm{~cm}$. End of 1st Sub-Boreal transgression. Comment: $64 \%$ sample; date based on 3 1-day counts. 
Lu-321. Färsksjön 4

$5360 \pm 100$

$\mathbf{3 4 1 0}$ в.C.

$\delta C^{13}=-21.0 \%$

Brackish gyttja, 601 to $605 \mathrm{~cm}$. End of 1st Sub-Boreal transgression. Comment: $57 \%$ sample.

\section{Lu-322. Färsksjön 5}

$5990 \pm 105$

4040 B.C.

Brackish gyttja, 659 to 663 cm transgression. Comment: $60 \%$ sample.

\section{Lu-323. Färsksjön 6}

$5940 \pm 100$

3990 B. C.

Brackish gyttja, 674 to $678 \mathrm{~cm}$. End of 1st Late Atlantic transgression. Comment: $61 \%$ sample; date based on 3 l-day counts.

\section{Lu-324. Färsksjön 7}

$6720 \pm 80$

sgression. Comment: $96 \%$ sample.

\section{Lu-325. Färsksjön 8}

4770 B.C.

$\delta C^{13}=-25.0 \%$

Slightly brackish gyttja, 714 to $718 \mathrm{~cm}$. Beginning of Early Atlantic

$6780 \pm 85$ 4830 в.c.

Limnic gyttja, 718 to $722 \mathrm{~cm}$. Just before beginning of Early Atlantic transgression. Comment: $89 \%$ sample.

\section{B. England}

\section{Lu-327. Chilton Track, Somerset Levels}

Wood (Corylus) id. by F. A. Hibbert, from prehistoric trackway in Somerset, England ( $51^{\circ} 11^{\prime} \mathrm{N}$ Lat, $02^{\circ} 50^{\prime} \mathrm{W}$ Long). Trackway is within fen-wood peat ca. $110 \mathrm{~cm}$ above marine clay and ca. $30 \mathrm{~cm}$ below transition to ombrogenous peat. Coll. 1969 by J. M. Coles and F. A. Hibbert; subm. by F. A. Hibbert, Sub-Dept. Quaternary Research, Univ. of Cambridge. Comment: for other dates from similar trackways in Somerset Levels, see Somerset Levels series and Lu-297, Lu-298 (R., 1970, v. 12, p. 596-597, 549). Pretreated with $\mathrm{HCl}$ and $\mathrm{NaOH}$.

\section{Lu-328. Baker Field Platform, Somerset Levels $4280 \pm 65$ 2330 B.c. $\delta C^{13}=-27.4 \%$ \\ Wood (Alnus) id. by F. A. Hibbert, from prehistoric platform in Somerset, England ( $51^{\circ} 11^{\prime} \mathrm{N}$ Lat, $02^{\circ} 50^{\prime} \mathrm{W}$ Long). Platform sits in fen-wood peat which overlies Phragmites fen peat and is covered by ombrogenous Sphagnum-Calluna-Eriophorum peat. Platform is at land-}


ward edge of Neolithic trackway complex (Coles and Hibbert, 1968). Pretreated with $\mathrm{HCl}$ and $\mathrm{NaOH}$. Coll. 1969 and subm. by F. A. Hibbert.

\section{Indian Ocean}$$
\mathbf{2 6 , 7 0 0}+580
$$$$
-\mathbf{5 4 0}
$$

Lu-336. Indian Ocean, Core 157

24,750 в.C.

$\delta C^{13}= \pm 0.0 \%$

Foraminifera tests from deep sea core No. $157\left(08^{\circ} 05^{\prime} \mathrm{N}\right.$ Lat, $53^{\circ} 03^{\prime}$ E Long), Indian Ocean; depth $5100 \mathrm{~m}$; depth in core 91.5 to $99.5 \mathrm{~cm}$. Coll. 1948 by Swedish Albatross Expedition; subm. by E. Olausson, Marine Geol. Lab., Univ. of Göteborg. Comment: sample ultrasonically washed in distilled acidified water ( $\mathrm{pH} 3$ to 4), and sieved by subm. Fraction $>65 \mu$ was used. Outermost $20 \%$ removed by acid leaching. Date based on two 2-day counts. For previous dates on Indian Ocean core, see Indian Ocean series (R., 1969, v. 11, p. 516-517).
\end{abstract}

\title{
II. ARChAEOLOGIC SAMPLES
}

\section{A. Sweden}

\section{Hagestad series}

Bone, charcoal, and wood from Hagestad, Löderup parish, Scania. Coll. 1969 and subm. by M. Strömberg, Hist. Mus., Univ. of Lund. Several samples were dated previously (R., 1968, v. 10, p. 48-50; 1969, v. 11 , p. $447-448 ; 1970$, v. 12 , p. 550-552). Charcoal and wood pretreated with $\mathrm{HCl}$ and $\mathrm{NaOH}$. Bone samples treated as described previously (R., 1970 , v. 12, p. 534).

\section{Lu-329. Hagestad $6^{2}$ A, Trench 1, wood}

$$
\begin{aligned}
& 1960 \pm \mathbf{5 5} \\
& 10 \text { B.C. } \\
& \delta C^{13}=-25.9 \% \%
\end{aligned}
$$

Wooden peg from Trench 1:1969, on Field S of brook at coast rd., Hagestad $6^{2} \mathrm{~A}\left(55^{\circ} 23^{\prime} \mathrm{N}\right.$ Lat, $14^{\circ} 09^{\prime} \mathrm{E}$ Long). Peg was sharpened and put into lake sand, forming part of fishing implement. Assoc. with pottery with faceted rim.

\section{Lu-330. Hagestad $6^{2}$ A, Trench 1, bone}

$$
\begin{gathered}
\mathbf{2 1 0 0} \pm \mathbf{5 5} \\
\mathbf{1 5 0} \text { B.C. } \\
\delta C^{13}=-19.8 \% 0
\end{gathered}
$$

Collagen from bone of cattle from lower stratum in Trench 1:1969, on same field as Lu-329. Comment: organic carbon content: $5.7 \%$.

\section{Lu-373. Hagestad $6^{2}$ A, charcoal}

$$
8650 \pm 105
$$

Charcoal and partly charred hazelnut shells from pit with solely Mesolithic finds, on same field as Lu-329 and Lu-330. Comment: sample undersized; diluted; $81 \%$ sample. 


\section{Lu-372. Hagestad 22 ${ }^{6}$, Trench 1}

Charcoal from hearth, 70 to $90 \mathrm{~cm}$ below surface, Trench 1:1969, at $\mathrm{S}$ border of Hagestads Mosse, Hagestad $22^{6}\left(55^{\circ} 23^{\prime} \mathrm{N}\right.$ Lat, $14^{\circ} 11^{\prime}$ E Long). Assoc. with Neolithic pottery.

\section{Lu-351. Hagestad $2^{2}$ B, bone}

$4040 \pm 65$ 2090 B.C.

$$
\delta C^{13}=-20.1 \%
$$

Collagen from poorly preserved bone fragments from feature $\mathrm{W}$ of megalithic grave at Hagestad $2^{2} \mathrm{~B}\left(55^{\circ} 25^{\prime} \mathrm{N}\right.$ Lat, $14^{\circ} 08^{\prime} \mathrm{E}$ Long). Comment: organic carbon content: $3.7 \%$.

General Comment (M.S.): date for Lu- 372 is too young, other dates are satisfactory, supporting archaeologic judgment.

\section{Lu-350. Ingelstorp 25}

$4140 \pm 75$

2190 B.C.

Collagen from poorly preserved human femur from floor in $\mathrm{NE}$ niche, Sec. C, in megalithic grave at Ingelstorp 25, Ingelstorp parish, Scania (55 $26^{\prime} \mathrm{N}$ Lat, $14^{\circ} 01^{\prime} \mathrm{E}$ Long). Coll. 1969 and subm. by $\mathrm{M}$. Strömberg. Comments (M.S.): date indicates burial is not from primary use of megalithic grave but from later in Middle Neolithic. (S.H.): organic content: $2.44 \%$. Sample undersized; diluted; $75 \%$ sample.

\section{Östra Tommarp series}

Human bones from excavation of grave fields at Östra Tommarp, SE

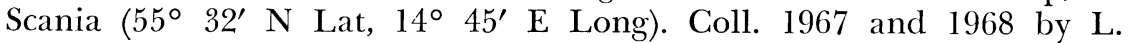
Redin; subm. by E. Cinthio, Hist. Mus., Univ. of Lund. During 1959 and 1960 excavations were carried out in part of area where medieval town of Tumathorp with its monastery was situated (Thun, 1967). Investigations were continued in 1967. Bones dated to support archaeologic dates of monastery and other parts of medieval site. Bone samples treated as described previously (R., 1970, v. 12, p. 534).

\section{Lu-385. Tommarp, Trench HI, Grave 1}

$$
\mathbf{8 9 0} \pm 50
$$

A.D. 1060

$$
\delta C^{13}=-20.0 \%
$$

Collagen from human femur, Trench HI:1967, Grave 1, in dark humus on yellow clay. Comment: organic carbon content: $5.3 \%$.

\section{Lu-386. Tommarp, Trench HI, Grave 2}

$$
580 \pm 45
$$

Collagen from human femur, Trench HI:1967, Grave 2, in dark humus on yellow clay. Comment: organic carbon content: $5.5 \%$. 


\section{Lu-387. Tommarp, Trench AB, Grave 12}

$$
920 \pm 50
$$

A.D. 1030

$\delta C^{13}=-20.0 \%$

Collagen from human femur, Trench AB:1968, Grave 12, in dark humus on yellow clay. Comment: organic carbon content: $4.3 \%$.

\section{Lu-388. Tommarp, Trench AB, Grave 13}

$$
890 \pm 50
$$

\section{A.D. 1060}

$\delta C^{13}=-20.7 \%$

Collagen from human femur, Trench AB:1968, Grave 13, in dark humus on yellow clay. Comment: organic carbon content: $4.0 \%$.

\section{Lu-389. Tommarp, Trench AB, Grave 15}

$$
\mathbf{8 7 0} \pm 50
$$

\section{A.D. 1080}

$\delta C^{13}=-19.1 \%$

Collagen from human femur, Trench AB:1968, Grave 15, in dark humus on yellow clay. Comment: organic carbon content: $6.4 \%$. General Comment (L.R.): dates support 2 different theories: 1) existence of developed settlement in 11th century, 2) existence of 2 churches in this early period, one of which was situated where later in 12th century a monastery was founded. So far it has not been possible to base these theories on archaeologic observations only.

\section{Gårdlösa series}

Charcoal and bone samples from Gårdlösa, Smedstorp parish, SE Scania (55 $34^{\prime} \mathrm{N}$ Lat, $14^{\circ} 08^{\prime} \mathrm{E}$ Long). Coll. 1960 to 1969 and subm. by B. Stjernquist, Hist. Mus., Univ. of Lund. Dated for investigation of continuity of settlement in Gårdlösa area (Stjernquist, 1964, 1965). For other dates from this area, see R., 1969, v. 11, p. 445-447. Charcoal samples pretreated with $\mathrm{HCl}$ and $\mathrm{NaOH}$. Bone sample treated as described previously (R., 1970, v. 12, p. 534).

\section{Lu-390. Gårdlösa No. 3, House II}

$$
1370 \pm 50
$$

\section{A.D. 580}

$\delta C^{13}=-24.9 \%$

Charcoal from cultural layer in house foundation, Gårdlösa No. 3, House II. Assoc. with sherds of pottery and spindle whorls. Coll. 1960.

\section{Lu-391. Gärdlösa No. 3, House IV}

$$
1350 \pm 50
$$

\section{A.D. 600}

$\delta C^{13}=-24.3 \%$

Charcoal from cultural layer in house foundation, Gårdlösa No. 3, House IV. Assoc. with sherds of pottery. Coll. 1963.

\section{Lu-392. Gårdlösa No. 3, House XIII}

$$
\begin{aligned}
& \mathbf{1 4 0 0} \pm \mathbf{5 0} \\
& \text { A.D. 550 } \\
& \delta C^{13}=-23.5 \%
\end{aligned}
$$

Charcoal from cultural layer in house foundation, Gårdlösa No. 3, House XIII. Assoc. with sherds of pottery, iron objects, and a glass bead. Coll. 1964. 


\section{Lu-393. Gårdlösa No. 3, House XLV}

$1290 \pm 50$

A.D. 660

$\delta C^{13}=-24.1 \%$

Charcoal from cultural layer in house foundation, Gårdlösa No. 3, House XLV. Assoc. with iron key, pottery, and spindle whorls. Coll. 1965.

\section{Lu-394. Gårdlösa No. 3, House L}

$$
\begin{aligned}
& 1250 \pm \mathbf{5 0} \\
& \text { A.D. } 700 \\
& \delta C^{13}=-23.6 \%
\end{aligned}
$$

Charcoal from cultural layer in house foundation, Gårdlösa No. 3, House L. Assoc. with bronze amulet with figural picture. Coll. 1966.

\section{Lu-395. Gårdlösa No. 3, House LII}

$$
\begin{gathered}
\mathbf{1 3 5 0} \pm \mathbf{5 0} \\
\text { A.D. 600 } \\
\delta C^{13}=-25.2 \%
\end{gathered}
$$

Charcoal from cultural layer in house foundation, Gårdlösa No. 3, House LII. Assoc. with silver pendant, sherds of pottery, and glass beads. Coll. 1966.

\section{Lu-396. Gårdlösa No. 3, House LIII}

$$
\begin{aligned}
& \mathbf{1 2 5 0} \pm \mathbf{5 0} \\
& \text { A.D. } 700 \\
& \delta C^{13}=-24.3 \% \text { o }
\end{aligned}
$$

Charcoal from cultural layer in house foundation, Gårdlösa No. 3, House LIII. Assoc. with bronze ornament, ring needle, glass beads, and sherds of pottery. Coll. 1969.

\section{Lu-399. Gårdlösa No. 3, Grave 66}

$$
\begin{aligned}
& 1680 \pm 80 \\
& \text { A.D. } 270 \\
& \delta C^{13}=-20.0 \%
\end{aligned}
$$

Collagen from human bone from Grave 66, Gårdlösa No. 3. Assoc. with iron buckle, iron knife, and pottery. Coll. 1969. Comment: organic carbon content: $1.7 \%$. Sample undersized; diluted; $49 \%$ sample.

\section{Lu-397. Gårdlösa No. 16, Sample 1}

$$
\begin{gathered}
\mathbf{1 8 8 0} \pm \mathbf{5 5} \\
\text { A.D. } \mathbf{7 0} \\
\delta C^{13}=-25.2 \% \text { c }
\end{gathered}
$$

Charcoal from hearth in cultural layer, Gårdlösa No. 16, P. 9-10. Coll. 1966.

\section{Lu-398. Gårdlösa No. 16, Sample 2}

$$
\begin{array}{r}
\mathbf{1 7 6 0} \pm \mathbf{5 5} \\
\text { A.D. } 190 \\
\delta C^{13}=-24.6 \%
\end{array}
$$

Charcoal from hearth in cultural layer, Gårdlösa No. 16, R. 29/3032/33. Coll. 1966.

General Comment (B.S.): all dates agree well with estimates based on archaeologic material.

\section{Torkö-östanön series, submarine blocking}

Wood samples from artificial blocking at ca. $5 \mathrm{~m}$ depth in strait between Torkö and östanön Is., Listerby, Blekinge $\left(56^{\circ} 09^{\prime} \mathrm{N}\right.$ Lat, $15^{\circ}$ 
25' E Long). Coll. 1969 by Blekinge Mus.; subm. by B. E. Berglund. Other dates from similar blockings were reported previously (R., 1968, v. 10 , p. 50; 1969, v. 11, p. 448-449). Pretreated with $\mathrm{HCl}$ and $\mathrm{NaOH}$.

\section{Lu-411. Torkö-östanön 1}

$$
\begin{aligned}
& \quad \mathbf{1 5 0} \pm \mathbf{5 0} \\
& \text { A.D. } 1800 \\
& \delta C^{13}=-24.6 \%
\end{aligned}
$$

Wood from birch pile. Sample taken from 5 youngest annual rings of 14-yr old trunk.

\section{Lu-412. Torkö-östanön 2}

$$
\begin{aligned}
& \quad \mathbf{1 1 0} \pm \mathbf{5 0} \\
& \text { A.D. 1840 } \\
& \delta C^{1 s}=-25.2 \% \text { o }
\end{aligned}
$$

Wood from spruce pile. Sample taken from 10 youngest annual rings of ca. 30-yr old trunk.

\section{Lu-413. Torkö-Östanön 3}

$$
\begin{aligned}
& \mathbf{1 8 0} \pm \mathbf{5 0} \\
& \text { A.D. } 1770 \\
& \delta C^{1 s}=-25.5 \% 0
\end{aligned}
$$

Wood from birch pile. Sample taken from 5 youngest annual rings of ca. 15-yr old trunk.

General Comment (B.E.B.): other blockings in Blekinge belonging to a defense system were dated to 11th century A.D., but low age of these piles indicates that they may belong to a blocking for fishing used in modern time.

\section{B. Argentina}

\section{Lu-370. Río Diablo, Site No. 3}

$$
1410 \pm 50
$$

\section{A.D. 540}

$$
\delta C^{13}=-23.3 \%
$$

Charcoal from Grid A, Level 3, Site No. 3, Río Diablo, La Ciénaga,

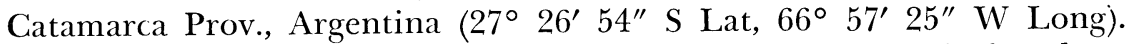
Assoc. with material from La Aguada culture, for which only few dates are so far known (González, 1961). Coll. 1969 by A. Risso; subm. by A. Rex González, Dept. of Archaeol., Mus. of La Plata, Argentina. Pretreated with $\mathrm{HCl}$ and $\mathrm{NaOH}$. Comment (A.R.G.): our guess was 700-850 A.D.; date somewhat early, but within possibilities of Aguada's beginning, especially if we take 2 sigmas.

\section{Lu-369. Agua Verde, Test No. 2}

$$
\begin{aligned}
& \mathbf{8 4 0} \pm \mathbf{5 0} \\
& \text { A.D. } 1110 \\
& \delta C^{13}=-24.0 \% \text { o }
\end{aligned}
$$

Charcoal from Test No. 2, Level 1, Site Agua Verde, Puerta de Corral Quemado, Catamarca Prov., Argentina (27 $27^{\prime} \mathrm{S}$ Lat, $66^{\circ} 57^{\prime}$ W Long). Assoc. with material from Hualfín culture, for which no dates are so far known (González, 1964). Coll. 1969 by C. Sempe and M. D. Arena; subm. by A. Rex González. Pretreated with HCl and NaOH. Comment (A.R.G.): archaeol. estimation 900-1000 A.D. 


\section{Lu-371. Eje de Hualfín, Room 72}

Charcoal from Room 72, depth $60 \mathrm{~cm}$, Eje de Hualfín, Dept. of Belén, Catamarca Prov., Argentina (27 $16^{\prime} 48^{\prime \prime} \mathrm{S}$ Lat, $66^{\circ} 51^{\prime} 42^{\prime \prime} \mathrm{W}$ Long). Assoc. with material from Belén culture (González, 1963). Coll. 1969 by C. Podestá; subm. by A. Rex González. Pretreated with HCl and $\mathrm{NaOH}$. Comment (A.R.G.): date in perfect accordance with our previous calculus and expectations and also with historical information of Inca arrival in Northwest Argentina; it is a good landmark for chronology of beginning of Belen III culture.

III. SOIL SCIENCE SAMPLES

\section{Linnebjer series}

Samples from deciduous forest and meadow soil profiles at Linnebjer, S Sandby parish, S Scania, Sweden $\left(55^{\circ} 44^{\prime} \mathrm{N}\right.$ Lat, $13^{\circ} 18^{\prime} \mathrm{E}$ Long). Dated to investigate possibility of using activity measurements as index of rate of turnover of organic matter in forest and meadow eco-systems (cf. Rafter and Stout, 1970). Oats cultivated next to experimental area and living matter from sampling points were used as integrators of activity during growth period 1969. Coll. Dec. 1962 (Lu-365), Nov. 1966 (Lu-364), and Nov. 1969, and subm. by F. Andersson, Dept. of Plant Ecol., Univ. of Lund. Both forest and meadow situated on clayey soil with hydromorphic features. Vegetational and environmental conditions of Linnebjer area are described by submitter (Andersson, 1970a, 1970b). No chemical pretreatment of samples.

Results are given as a difference, $\Delta$, from our radiocarbon standard $(95 \%$ of the activity of NBS oxalic acid standard, not age corrected to 1950):

$$
\Delta=\delta \mathrm{C}^{14}-\left(2 \delta \mathrm{C}^{13}+50\right)\left(1+\frac{\delta \mathrm{C}^{14}}{1000}\right)
$$

where $\delta \mathrm{C}^{14}$ is observed deviation from radiocarbon standard in per mil and $\delta \mathrm{G}^{13}$ deviation from P.D.B. standard in per mil.

Final results of investigation will be published later elsewhere.

\section{Forest soil profile}

Brown forest soil with mull. Mull layer $10 \mathrm{~cm}$ and brown earth layer (B) ca. $25 \mathrm{~cm}$ thick. Depths given below refer to surface of mull layer.

\section{Lu-353. Linnebjer 2, Nov. 1969}

New litter of oak, hazel, and lime tree.

$$
\begin{gathered}
\Delta=+\mathbf{5 7 5} \pm \mathbf{7} \% \\
\delta C^{13}=-26.6 \%
\end{gathered}
$$

\section{Lu-354. Linnebjer 3, Nov. 1969}

$$
\begin{gathered}
\Delta=+\mathbf{5 5 2} \pm \mathbf{7} \% \\
\delta C^{13}=-27.3 \%
\end{gathered}
$$

Old litter. 
Lu-355. Linnebjer 4, Nov. 1969

$$
\begin{gathered}
\Delta=+\mathbf{5 0 6} \pm \mathbf{7} \% \\
\delta C^{13}=-26.4 \%
\end{gathered}
$$

Upper mull (dark humus), 0 to $2 \mathrm{~cm}$ depth.

Lu-356. Linnebjer 5, Nov. 1969

$\Delta=+41 \pm 6 \%$

$\delta C^{1 s}=-26.4 \%$

Mull, 2 to $10 \mathrm{~cm}$ depth.

Lu-357. Linnebjer 6, Nov. 1969

$\Delta=-162 \pm 6 \%$ $\delta C^{13}=-25.3 \%$

Brown earth from lower part of (B) layer, depth ca. $30 \mathrm{~cm}$. Comment: $\Delta=-162 \pm 6 \%$ corresponds to radiocarbon age $1420 \pm 50$ B.P.

Lu-364. Linnebjer 15, Nov. 1966

$\Delta=-\mathbf{1 1} \pm \mathbf{5} \%$ $\delta C^{13}=-25.8 \%$

Mull, 0 to $10 \mathrm{~cm}$ depth. Comment: $\Delta=-11 \pm 5 \%$ corresponds to radiocarbon age $80 \pm 40$ B.P.

Lu-365. Linnebjer 16, Dec. 1962

$\Delta=-\mathbf{1 4} \pm \mathbf{5} \%$ $\delta C^{13}=-26.4 \%$

Mull, 0 to $10 \mathrm{~cm}$ depth. Comment: $\Delta=-14 \pm 5 \%$ corresponds to radiocarbon age $110 \pm 40$ в.P.

\section{Meadow soil profile}

Mullgley soil with ca. $25 \mathrm{~cm}$ thick mull layer. Depths given below refer to surface of mull layer.

Lu-359. Linnebjer 9-10, Nov. 1969

$$
\begin{array}{r}
\Delta=+626 \pm 8 \% \\
\delta C^{13}=-27.6 \% \circ
\end{array}
$$

Litter of Filipendula ulmaria.

\section{Lu-360. Linnebjer 11, Nov. 1969}

$$
\begin{array}{r}
\Delta=+171 \pm 7 \% \circ \\
\delta C^{13}=-27.7 \% \circ
\end{array}
$$

Mull, 2 to $5 \mathrm{~cm}$ depth.

\section{Lu-361. Linnebjer 12, Nov. 1969}

Mull, 5 to $15 \mathrm{~cm}$ depth.

$\Delta=+89 \pm 6 \%$ $\delta C^{13}=-26.4 \%$

Lu-362. Linnebjer 13, Nov. 1969

$$
\begin{aligned}
& \Delta=-56 \pm \mathbf{6} \% \\
& \delta C^{13}=-24.9 \%
\end{aligned}
$$

Mull with sand in transition zone from $G_{0}$ layer to mull layer. Depth ca. $25 \mathrm{~cm}$. Comment: $\Delta=-56 \pm 6 \%$ corresponds to radiocarbon age $460 \pm 50$ в.P.

\section{Radiocarbon activity integrators}

$$
\begin{array}{ll}
\text { Lu-352. Linnebjer 1, Nov. } 1969 & \Delta=+577 \pm 7 \% \\
\delta C^{13}=-29.1 \% \circ
\end{array}
$$

Leaves of hazel coll. Nov. 11, 1969 on shrubs quite close to forest soil profile. 


\section{Lu-358. Linnebjer 8, Nov. 1969}

$$
\Delta=+\mathbf{5 6 6} \pm \mathbf{7} \%
$$

$\delta C^{13}=-26.4 \%$

Living matter of Filipendula ulmaria coll. Nov. 11, 1969 on surface of meadow soil profile.

\section{Lu-363. Linnebjer 14, 1969}

$$
\begin{array}{r}
\Delta=+\mathbf{5 7 9} \pm \mathbf{7} \% \\
\delta C^{13}=-25.2 \% 0
\end{array}
$$

Threshed grains of oats cultivated next to experimental area and coll. after harvest 1969.

\section{REFERENCES}

Andersson, Folke, 1970a, Ecological studies in a Scanian woodland and meadow area. I. Vegetational and environmental conditions: Op. Bot. A Soc. Bot. Lundensi, v. $27,190 \mathrm{p}$

1970b, Ecological studies in a Scanian woodland and meadow area. II. Plant biomass, primary production and turn-over of organic matter: Bot. Notiser (Lund), v. 123, p. 8-51.

Berglund, B. E., 1964, The Post-Glacial shore displacement in eastern Blekinge, southeastern Sweden: Sveriges Geol. Unders., ser. C., no. 599, p. 1-47.

- 1966a, Late-Quaternary vegetation in eastern Blekinge, southeastern Sweden. I. Late-Glacial time: Op. Bot. A Soc. Bot. Lundensi, v. 12, no. 1, 180 p. 1966b, Late-Quaternary vegetation in eastern Blekinge, southeastern Sweden. II. Post-Glacial time: Op. Bot. A Soc. Bot. Lundensi, v. 12, no. 2, 190 p 1971, Late-Glacial stratigraphy and chronology in South Sweden in the light of biostratigraphic studies on Mt. Kullen, Scania: Geol. För. Stockholm Förh., v. 95, p. $11-45$.

Coles, J. M. and Hibbert, F. A., 1968, Prehistoric roads and tracks in Somerset, England: Prehist. Soc. Proc., v. 34 , p. 238

González, A. Rex, 1961, The La Aguada culture of northwestern Argentina, in: Essays in Pre-Columbian art and archaeology, Cambridge, Mass., Harvard Univ. Press, p. $389-420$.

1963, Cultural development in northwestern Argentina, in: Smithsonian Misc. Colln., v. 146, no. 1, p. 103-117.

- 1964, Nuevas fechas de la cronología Argentina obtenidas por el método de radiocarbón (V): Rev. Inst. Antropol., Córdoba, Argentina, v. 2-3, p. 289-297.

Nilsson, 'Tage, 1935, Die pollenanalytische Zonengliederung der spät- und postglazialen Bildungen Schonens: Geol. För. Stockholm Förh., v. 57, p. 385-562.

- 1961a, Ein neues Standardpollendiagramm aus Bjärsjöholmssjön in Schonen: Lunds Univ. Årssk., N.F. avd. 2, v. 56, no. 18, p. 1-34.

1961b, Ravlundafältets geologi: Skånes Natur, 1961, Lund, p. 73-106.

1964, Standardpollendiagramme und $\mathbf{C}^{14}$-Datierungen aus dem Ageröds Mosse im mittleren Schonen: Lunds Univ. Årsk., N.F. avd. 2, v. 59, no. 7, p. 1-52.

Rafter, T. A. and Stout, J. D., 1970, Radiocarbon measurements as an index of the rate of turnover of organic matter in forest and grassland ecosystems in New Zealand, in: Olsson, I. U. (ed.), Radiocarbon variations and absolute chronology, 12th Nobel symposium proc., Uppsala, Aug. 1969, p. 407-417.

Sonesson, Mats, 1968, Pollen zones at Abisko, Torne Lappmark, Sweden: Bot Notiser (Lund), v. 121, p. 491-500.

1969, Studies on mire vegetation in the Torneträsk area, northern Sweden. III. Communities of the poor mires: Op. Bot. A Soc. Bot. Lundensi, v. 26, 120 p. 1970, Studies on mire vegetation in the Torneträsk area, northern Sweden. IV. Some habitat conditions of the poor mires: Bot. Notiser (Lund), v. 123, p. 67-111.

Stjernquist, Berta, 1964, New light on spring-cults in Scandinavian prehistory: Archaeology, v. 17, no. 3, p. 180-184.

1965, Gårdlösaundersökningen. En presentation: Ale, Hist. Tidskr. för Skảneland, no. 2 , 1965 , p. 12-23.

Thun, Egon, 1967, Medieval Tommarp, Archaeological investigations 1959-60: Acta Archaeologica Lundensia, ser. in $8^{\circ}$, no. 5,91 p. 